\title{
Kemampuan Literasi Sains Siswa Sekolah Dasar di Sekolah Adiwiyata (Studi Deksriptif di SD Adiwiyata X Kota Padang)
}

\author{
Safrizal1 ${ }^{1}$, Lenny Zaroha ${ }^{2}$, Resti Yulia ${ }^{3}$ \\ ${ }^{1}$ Pendidikan Guru Madrasah Ibtidaiyah, IAIN Batusangkar Sumatera Barat \\ ${ }^{2}$ Sekolah Dasar Negeri 22 Ujung Gurun Padang \\ ${ }^{3}$ Rumah Anak Sholeh 85 Padang \\ e-mail: \\ 1 safrizal@iainbatusangkar.ac.id \\ 2 lennyzaroha@yahoo.com \\ 3 restiyulia911@gmail.com
}

\begin{abstract}
.
The aims of this study is to describe the ability of scientific literacy of students in Adiwiyata's school on three aspects, they are content, context, and attitude. The importance of having scientific literacy is one of the competencies must be possessed in 21st century education. Adiwiyata School is one of the concrete steps of the government to instill the principles and competences of scientific literacy. The research method used is descriptive quantitative. The research sample was taken using simple random sampling technique. The data collection was carried out by distributing questions and questionnaires to students in Adiwiyata School. Then, the data was analyzed using descriptive statistics by referring to categorization norms. The results showed that the scientific literacy ability of elementary school students in Adiwiyata School was in the high category. Furthermore, the ability of scientific literacy aspects of attitudes in Adiwiyata school students is in the bigh category namely $X>$ 53.6. While the ability of scientific literacy in the aspect of content included in the category is quite low. The acquisition of scientific literacy skills in students at Adiniyata school is believed to be influenced by the characteristics of the school in internalizing the values of science in teaching and learning activities in the classroom.
\end{abstract}

Keywords: adiwiyata, scientific literacy, content, and context

\begin{abstract}
ABSTRAK.
Tujuan penelitian ini adalah untuk mendeskripsikan kemampuan literasi sains siswa di sekolah Adiwiyata pada tiga aspek, yakni konten, konteks, dan sikap. Pentingnya memiliki Literasi sains menjadi salah satu kompetensi yang harus dimiliki dalam pendidikan abad 21. Sekolah Adiwiyata menjadi salah satu langkah konkrit pemerintah untuk menanamkan prinsip dan kompetensi literasi sains. Metode penelitian yang digunakan adalah kuantitatif deskriptif. Pengambilan sampel penelitian dilakukan dengan teknik simple random sampling Pengumpulan data dilakukan dengan cara menyebarkan soal dan kuesioner kepada siswa di Sekolah Adiwiyata. Kemudian, data di analisis dengan menggunakan Statistik Deskriptif dengan merujuk pada norma kategorisasi. Hasil penelitian menunjukkan bahwa kemampuan literasi sains siswa sekolah dasar di Sekolah Adiwiyata berada pada kategori tinggi. Selanjutnya, kemampuan literasi sains aspek sikap pada siswa sekolah Adiwiyata berada pada kategori tinggi yakni X > 53,6. Sedangkan kemampuan literasi sains pada aspek konten termasuk dalam kategori cukup rendah. Pemerolehan kemampuan literasi sains pada siswa di sekolah Adiwiyata diyakini dipengaruhi oleh ke-khas-an sekolah dalam menginternalisasi nilai-nilai sains dalam aktivitas belajar mengajar di kelas.
\end{abstract}

Kata kunci: adiwiyata, literasi sains, konten, konteks, sikap. 


\section{PENDAHULUAN}

Literasi menjadi salah satu kompetensi yang harus dimiliki dalam menghadapi era pendidikan abad 21. Hal tersebut bermakna bahwa sebagai ujung tombak menyiapkan kompetensi abad 21, literasi sains menjadi ranah kemampuan yang sifatnya bukan hanya hafalan, namun berkaitan dengan aplikasi nilai-nilai sains dalam kehidupan sehari-hari (DeBoer, 2000; Eisenhart ET AL., 1996; Pratiwi et al., 2019). Konsep kunci literasi sains menjadi titik berat bahwa pendidikan Abad 21 bukan hanya menuntut peserta didik untuk bisa menghafal dan menerima banyak hal, namun pendidikan abad 21 menuntut agar peserta didik menyiapkan komunikasi, kolaborasi, berpikir kritis, dan kreatif (Frydenberg \& Andone, 2011; Pratiwi et al., 2019). Uraian tersebut jelas bahwa literasi sains penting bagi siswa untuk memahami lingkungan, kesehatan, social, modern, dan teknologi agar siswa memiliki kompetensi dan keterampilan untuk dapat meletakkan sains bukan hanya tataran konsep namun juga menjadikan sains sebagai tataran prinsip hidup dengan menjadikan sains sebagai sikap ilmiah, serta dapat menerapkan sains sebagai pemecahan masalah dalam kehidupan yang nyata dengan masyarakat yang berliterasi sains (Aberšek et al., 2015; Bond, 1989; DeBoer, 2000; Holbrook \& Rannikmae, 2009 ).

Programe for International Student Assessment (PISA) mengklarifikasi bahwa kemampuan literasi sains peserta didik Indonesia masih di bawah rata-rata skor internasional dan secara umum berada pada tahapan terendah PISA (Toharuddin, 2011). Sebagaimana dikutip dari The Organization for Economic Co-operation and Development (OECD) Tahun 2015 bahwa peringkat Indonesia di PISA berada pada 69 dari 71 negara yang diuji. Hasil tersebut mengindikasikan bahwa kemampuan literasi sains siswa di Indonesia masih berada di bawah rerata angka aman dari pengukuran PISA. Rendahnya literasi sains siswa juga diperkuat dengan hasil observasi yang peneliti lakukan di sebuah SD X di Kota Padang, rendahnya keterbukaan wawasan siswa dalam tindakan membuang sampah semabarangan, menggunakan kran air sebagai sarana bermain dan tidak mematikannya kembali menjadi salah satu hal yang sangat memprihatinkan, sementara harapan yang dinanti adalah lahirnya generasi emas abad 21 yang bukan hanya mahir dalam bidang pengetahuan, namun kaya akan tindakan aplikatif yang menjadikan sains sebagai solusi (Amali, Kurniawati, \& Zulhiddah, 2019). Permasalahan tersebut, didukung dengan beberapa hasil penelitian yang menyebutkan bahwa, rendahnya literas sains siswa ditengarai oleh proses pembelajaran yang belum memberikan peluang bagi peserta didik untuk mengembangkan kemampuan bernalar kritis, masih bercirikan transfer sains buka mengedepankan fakta, konsep, prinsip, dan hukum, tidak dikaitkan dengan konteks kehidupan nyata, serta cenderung hanya mengantisipasi ujian sehingga aspek sains sebagai proses dan sikap benar-benar terabaikan (Pertiwi et al., 2015; Susilastri \& Rustaman, 2015; Yuliati, 2017)

Berbagai pertemuan empiris yang telah dipaparkan sebelumnya merupakan indikasi bahwa sains belum diusahakan menjadikan siswa yang melek akan aplikasi ilmu sains, dan jelas masih berjalan secara konvensional. Bertolak belakangnya kenyataan dan harapan tentu menjadi catatan tersendiri dalam dunia pendidikan. Hal tersebut bermakna dunia pendidikan memerlukan langkah khusus pada pola pengajaran dan system sekolah guna membekali siswa kompetensi untuk menghadapi era ada 21. Upaya pemerintah dalam meningkatkan kemampuan literasi sains, yang saat ini menjadi polemic di dunia pendidikan, dan masih kurangnya pembahasan terkait dengan kemampuan literasi sains adalah program Adiwiyata. Adiwiyata sebagai salah satu upaya yang saat ini telah dilakukan pemerintah sebagai program terencana di sekolah guna memberikan pemahaman dan penanaman perilaku serta sikap memberdayakan alam dan lingkunan sedemikian rupa. Salah satu hasil yang diharapkan muncul dari program Adiwiyata adalah memperbanyak siswa yang paham akan pentingnya alam sebagai salah satu kebutuhan yang penting bagi keberlangsungan kehidupan di bumi.

Dukungan berbagai fasilitas yang ada di sekolah dengan program Adiwiyata menjaidkan sekolah yang mengadopsi program ini memiliki ke-khas-an tersendiri, baik dari segi program, sarana pendukung, serta brbagai fasilitas yang memadai untuk menjadikan siswa memiliki 
keterbukaan wawasan pemahaman bagi siswa terkait dengan literasi sains adalah keberadaan apotik hidup (TOGA), berbagai slogan pengetahuan sains, serta berbagai jenis lingkungan alam lainnya yang dapat menjadi suber informasi bagi siswa serta menjadi lingkungan yang esensial guna sebagai saranan bermain, belajar dan pengembangan diri siswa. Oleh sebab itu, penelitian ini menitik beratkan pada pembahasan kemampuan literasi sains siswa SD di Sekolah Adiwiyata sebagai progam sekolah dengan slogan peduli dan berbudaya lingkungan. Selain itu, penelitian ini diarahkan ada deksripsi kemampuan literasi sains pada tiga aspek yaitu konten, konteks, dan sikap, sehingga peneliti dapat menggambarkan secara keseluruhan kemampuan literasi sains siswa SD di Sekolah Adiwiyata pada tiga aspek literasi sains dengan mengacu pada indicator dari ketiga aspek tersebut.

\section{METODOLOGI}

Metode penelitian yang digunakan dalam penelitian ini adalah Kuantitatif deskriptif. Metode ini digunakan karena sesuai dengan tujuan penelitian yakni mendeskripsikan secara luas terkait gambaran variable yang diteliti, yakni tentang kemampuan literasi sains siswa pada aspek konten, konteks, dan sikap. Populasi dalam penelitian ini adalah Siswa Kelas V SD X Adiwiyata. Penarikan sampel dilakukan dengan menggunakan teknik simple random sampling. Instrument penelitian yang digunakan adalah soal-soal tentang literasi sains berbasis higher order thnking skilss (HOTS) untuk aspek konten, lembar observasi dan angket untuk aspek konteks dan sikap. Validasi instrument dilakukan dengan expert judgement. Data penelitian yang telah dihasilkan di analisis dengan statistic descriptive analytic yang kemudian dikategorisasikan dengan norma kategorisasi. Perhitungan norma kategorisasi didasarkan pada pendapat Azwar (2017) sebagai berikut:

Tabel 1. Norma kategorisasi

\begin{tabular}{cc}
\hline Rentang Skor & Kategori \\
\hline $\mathrm{X}>\mu+1 \sigma$ & Tinggi \\
\hline$\mu<\mathrm{X} \leq \mu+1 \sigma$ & Cukup Tinggi \\
\hline$\mu-1 \sigma<\mathrm{X} \leq \mu$ & Cukup Rendah \\
\hline $\mathrm{X} \leq \mu-1 \sigma$ & Rendah \\
\hline
\end{tabular}

Hasil perhitungan norma kategorisasi berdasarkan rumus yang digunakan untuk aspek konten dan sikap terlihat pada tabel berikut.

Tabel 2. Perhitungan norma kategorisasi untuk aspek sikap dan konten

\begin{tabular}{cc}
\hline Rentang Skor Aspek Konten & Kategori \\
\hline $\mathrm{X}>30,3$ & Tinggi \\
\hline $26<\mathrm{X} \leq 30,3$ & Cukup Tinggi \\
\hline $21,7<\mathrm{X} \leq 26$ & Cukup Rendah \\
\hline $\mathrm{X} \leq 21,7$ & Rendah \\
\hline Rentang Skor Aspek Sikap & Kategori \\
\hline $\mathrm{X}>53,6$ & Tinggi \\
\hline $46<\mathrm{X} \leq 53,6$ & Cukup Tinggi \\
\hline $38,4<\mathrm{X} \leq 46$ & Cukup Rendah \\
\hline $\mathrm{X} \leq 38,4$ & Rendah \\
\hline
\end{tabular}




\section{TEMUAN DAN PEMBAHASAN}

Aspek Konteks literasi sains merupakan topik khusus yang membahas tentang pengetahuan pemecahan masalah yang berkaitan dengan kehidupan sehari-hari. Berdasarkan hasil tes yang dilakukan pada lima topic pembahasan, diperoleh hasil kemampuan literasi sains siswa SD di Sekolah Adiwiyata pada aspek kontes, terlihat pada rekapitulasi tabel di bawah ini.

Tabel 3. Tabulasi penyelesaian soal literasi sains

\begin{tabular}{lcccccc}
\hline Topik Konteks & Soal & Benar & $\%$ & Salah & $\%$ & Total \\
\hline Kupu - kupu dan Petani & $1 / 1$ & 25 & 100 & 0 & 0 & 100 \\
\cline { 2 - 6 } & $1 / 2$ & 24 & 96 & 1 & 4 & 100 \\
\hline Bagaimana Makhluk Hidup & $2 / 1$ & 1 & 96 & 24 & 96 & 100 \\
\cline { 2 - 7 } Beradaptasi ? & $2 / 2$ & 21 & 84 & 4 & 16 & 100 \\
\hline Kemana Perginya Capung? & $3 / 1$ & 5 & 20 & 20 & 80 & 100 \\
\cline { 2 - 6 } & $3 / 2$ & 9 & 36 & 16 & 64 & 100 \\
\hline Kehebatan Cahaya & $4 / 1$ & 10 & 40 & 15 & 60 & 100 \\
\cline { 2 - 6 } & $4 / 2$ & 10 & 40 & 15 & 60 & 100 \\
\hline Kabut Asap dan Penyakit & $5 / 1$ & 15 & 60 & 10 & 40 & 100 \\
ISPA & $5 / 2$ & 8 & 32 & 17 & 68 & 100 \\
\hline Rata-rata Menjawab Benar & & 13 & 52 & 12 & 48 & 100 \\
\hline
\end{tabular}

Hasil pada tabel di atas dapat di deskripsikan bahwa rata-rata jumlah siswa yang menjawab benar pada lima topic soal terkait dengan aspek konteks literasi sains hanya berjumlah 13 siswa atau setara dengan $52 \%$. Besarnya persentase siswa yang menjawab dengan kategori benar pada lima topic yang disajikan hakikatnya berada pada kategori lebih besar dari setengahnya. Artinya, lebih dari setengah dari jumlah seluruh siswa yang diuji mampu menjawab benar soal yang diujikan. Hal tersebut juga berlaku sebaliknya bagi siswa yang menjawab salah. Gambaran umum kemampuan literasi sains pada aspek konteks, tergambar pada grafik berikut.

Deskripsi Kemampuan Literasi Sains Siswa Aspek Konteks Sekolah Adiwiyata

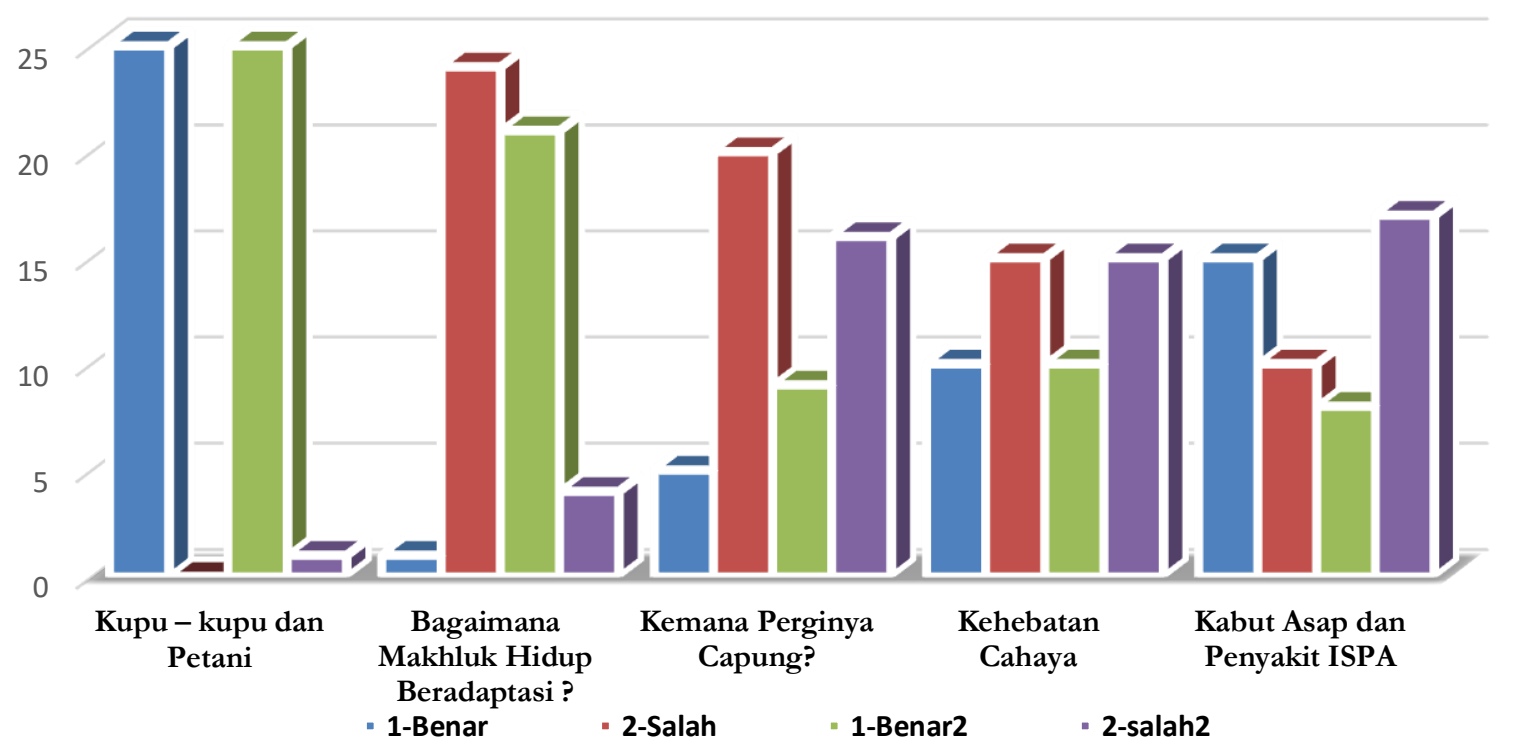

Gambar 1. Grafik deskripsi kemampuan literasi sains siswa aspek konteks 
Grafik di atas memperjelas bahwa kemampuan siswa dalam menjawab soal literasi sains khusunya pada aspek konteks berada pada kategori cukup. Siswa sudah mampu untuk mengidentifikasi bukti ilmiah mengenai adaptasi makhluk hidup berdasarkan fenomena dan kejadian yang ditemukan dalam kehidupan sehari-hari, mampu menjelaskan simbiosis yang terjadi antara kupu-kupu dan petani, serta berbagai topic lainnya sudah cukup mampu diselesaikan dengan baik berdasarkan jawaban yang telah diberikan. Temuan ini menjadi landasan terkait dengan bagaimana menggunakan pengetahuan ilmiah sebagai pijakan dalam menyelesaikan masalah dan mengambil keputusan yang ditemu dalam kehidupan sehari-hari.

Aspek konten berkaitan dengan konsep kunci yang diperlukan untuk dapat mehamai fenomena alam dan berbagai perubahan yang dilakukan terhadap alam melalui aktivitas manusia. Hasil penelitiann yang berkaitan dengan kemampuan literasi sains pada aspek konten siswa SD Adiwiyata berdasarkan lembar pengamatan yang dilakukan selama tiga hari diperoleh hasil yang terlihat pada gambar berikut.

\section{Deskripsi Kemampuan Literasi Sains Aspek Konten Siswa Adiwiyata}

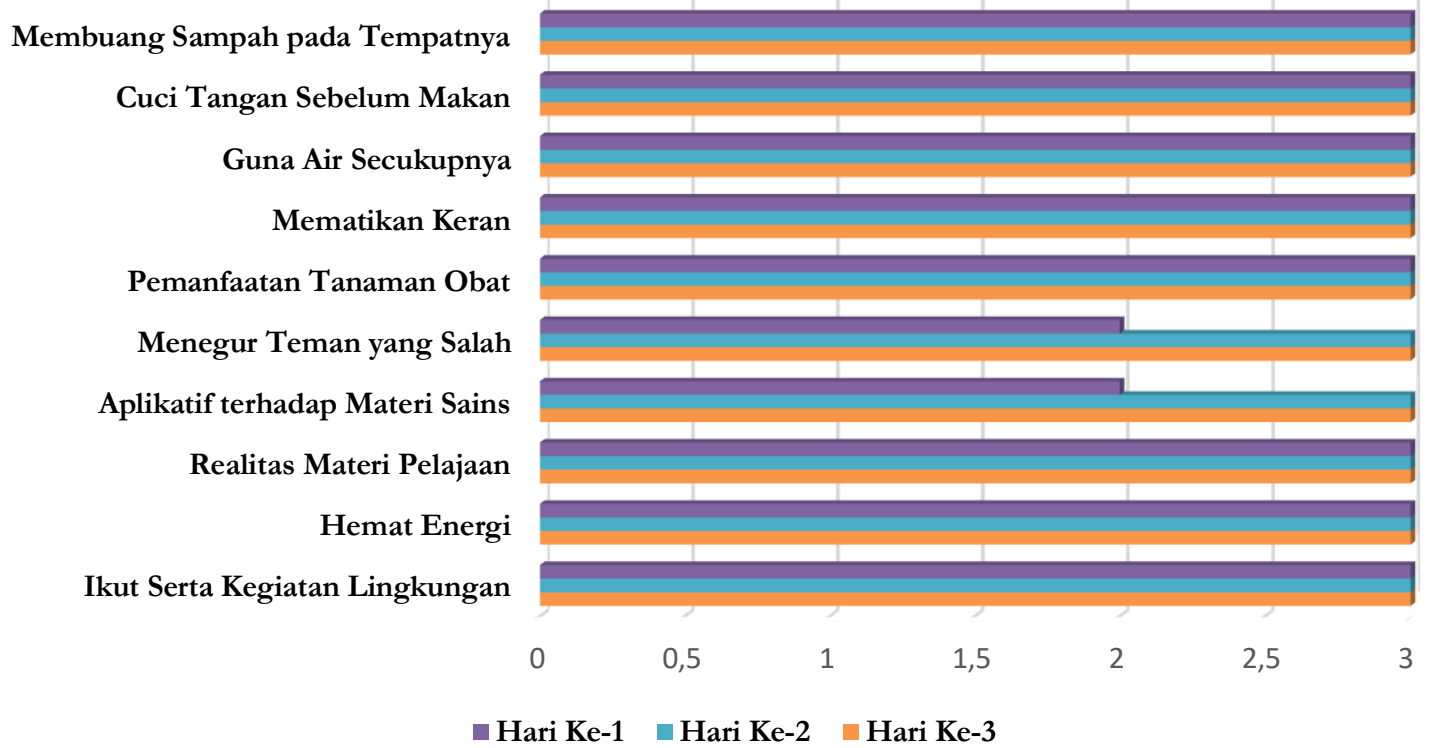

Gambar 2. Tabulasi kemampuan literasi sains pada aspek konten

Grafik di atas menggambarkan bahwa kemampuan literasi sains pada aspek konten siswa SD Adiwiyata stabil berada pada skala 3 dari 3 skala pengukuran yang disajikan dengan kategori selalu Nampak. Hal tersebut menunjukkan bahwa kemampuan literasi sains siswa pada aspek konten sebagaimana kembar pengamatan terkait dengan kegiatan-kegiatan atau perilaku yang terlihat sudah masuk dalam kategori selalu Nampak atau sudah membudaya. Pernyataan tersebut diperkuat dengan beberapa item pengamatan sebagaimana terterera pada grafik di atas. Rata-rata seluruh aspek konten berada pada jenjang skala 3 dengan range skala 1-3. Kemampuan literasi sains pada aspek konten untuk siswa SD di Sekolah Adiwiyata berada pada kategori tinggi sebagaimana norma kategorisai aspek konten yang berada pada rentang $\geq 30,3$. Tercapainya aspek konten literasi sains pada kategori tinggi untuk siswa sekolah Adiwiyata bermakna bahwa secara aplikatif fenomena-fenomena sains yang aplikatif dilakukan sehari-hari telah menjadi budaya di kalangan siswa Sekolah Adiwiyata terkait dengan kesadaran dalam menjaga aspek-aspek pribadi, kelompok, dan lingkungan tempat mereka tinggal. 
Hasil penelitian terkait kemampuan literasi sains siswa SD di Sekolah Adiwiyata memiliki kategroi yang sama dengan aspek konten. Pada aspek sikap, peneliti menyajikan beberapa permasalahan yang kemudian disusun kedalam angket yang berisi tentang pernyataan berkaitan dengan lingkungan dan problematika alam yang erat kaitannya dengan kehidupan sehari-hari. Secara umum, tabulasi data hasil penelitian tergambar pada grafik berikut.

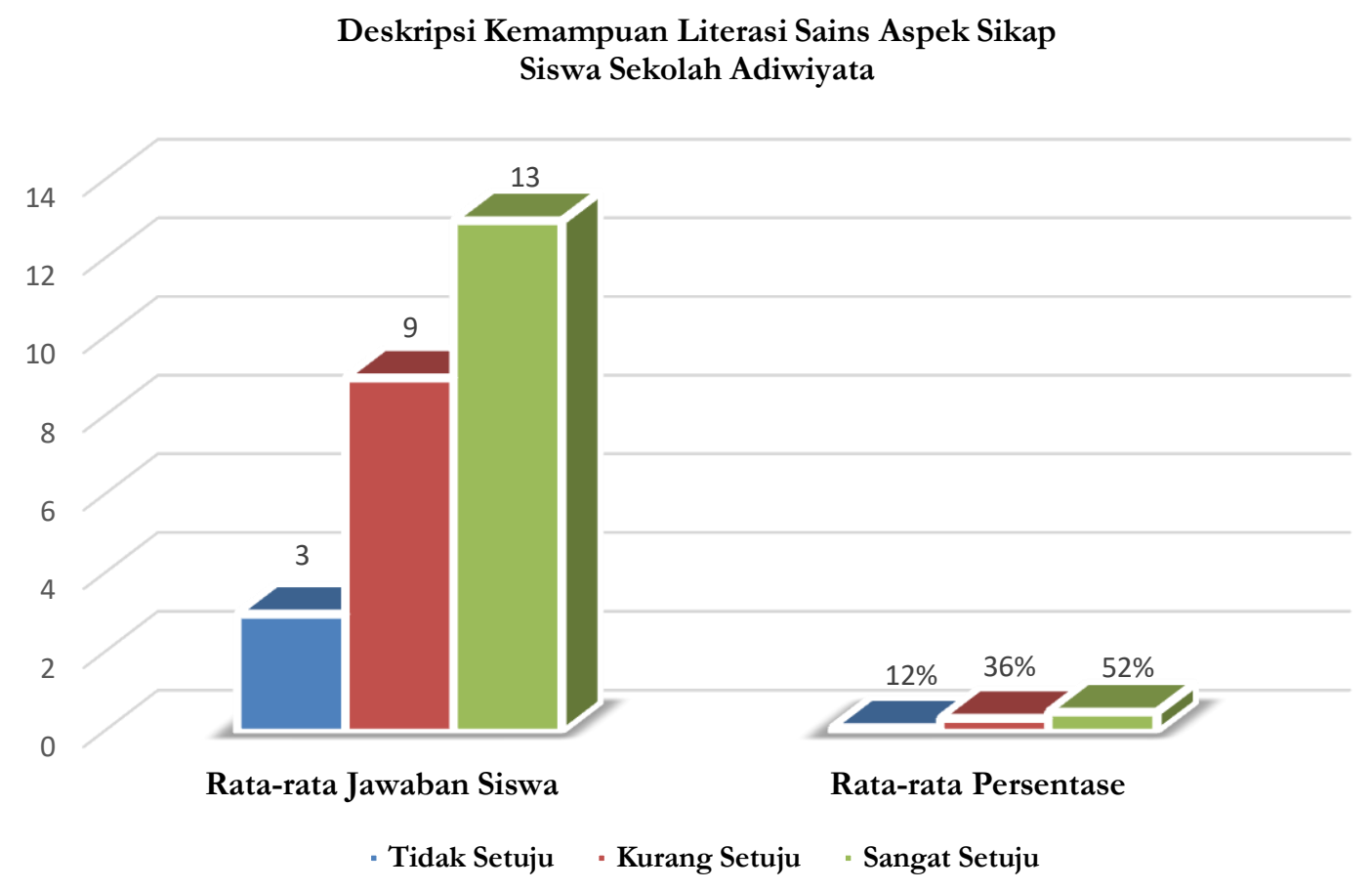

Gambar 3. Grafik kemampuan literasi sains aspek sikap

Grafik di atas merupakan gamabaran kemampuan literasi sains aspek sikap pada siswa di Sekolah Adiwiyata. Berdasarkan grafik tersebut terlihat bahwa rata-rata jumlah siswa yang menjawab dengan pernyataan tidak setuju pada ketiga ranah aspek sikap berjumlah 3 orang atau setara dengan $12 \%$. Demikian juga untuk jawaban kurang setuju dan sangat setuju, masingmasing berjumlah 9 orang atau $36 \%$ untuk yang menjawab kurang setuju, dan 13 orang atau $52 \%$ siswa menjawab setuju. Pengkategorisasian kemampuan literasi sains pada aspek sikap sebagaimana ditunjukkan pada grafik di atas menunjukkan rerata perolehan skro dari masingmasing item di jawab oleh 25 siswa sebersar 60 poin. Merujuk pada norma kategorisasi sebagaimana yang tertera pada tabel perhtiungan norma kategorisasi menunjukkan bahwa kemampuan siswa sekolah Adiwiyata pada aspek sikap berada pada rentang nilai X > 53,6 yang berarti kemampuan aspek sikap literasi sains berada pada kategori tinggi. Tingginya perolehan ini, diperoleh karena SD Adiwiyata menyajikan berbagai kegiatan menarik dan sejumlah papan informasi yang bisa ditemukan oleh siswa di setiap sudut sekolah. Sehingga, ini lah yang menjadi salah satu alasan kuat yang membentuk sikap literasi sains siswa.

Penelitian ini dilakukan dengan tujuan untuk mendeskripsikan kemampuan literasi sains siswa SD di Sekolah Adiwiyata pada tiga aspek, yakni konten, konteks, dan sikap. Selain itu, penelitian ini dilaksanakan guna memberikan informasi terkait dengan kompetensi keterampilan abad 21 yang sudah seharusnya dimiliki oleh generasi muda Indonesia, khususnya siswa sekolah dasar yang merupakan cikal bakal generasi yang akan menghadapi abad 21. Literasi sains menjadi salah satu kompetensi yang harus dimiliki pada abad 21 karena literasi bukan hanya berkaitan dengan kemampuan menghafal banyak pengertian, namun bagaimana mengaplikasikan dan menjadikan penetahuan yang diperoleh untuk memecahkan permasalahan kehidupan sehari-hari berdasarkan konsep-konsep sains. Salah satu hal sederhana pentingnya penelitian ini diangkat adalah bahwa literasi sains perlu ditanamkan sedini mungkin, agar siswa terbiasa dengan 
mengaplikasikan konsep sains sebagai pemecahan masalah yang berkaitan dengan kehidupan seahri. Sehingga, ilmu yang diperoleh di sekolah teraplikasikan dengan baik.

Hasil penelitian dari ketiga aspek literasi sains pada sekolah Adiwiyata diperoleh bahwa dalam hal mengidentifikasi permasalahan dan mengaitkan keterhubungan satu dengan yang lainnya, siswa sekolah Adiwiyata sudah memiliki kecakapan terutama dalam mengungkapkan alasan - alasan atau penyebab yang terjadi sebagaimana topik pembahasan yang disajikan. hal ini dapat dimaknai bahwa sekolah Adiwiyata memiliki keunggulan yang menyajikan peduli lingkungan sebagai salah satu kunci utama yang tidak dimiliki oleh sekolah yang tidak adiwiyata. Pengetahuan atau penguasaan konteks yang berkaitan dengan alam akan menjadikan siswa memiliki pengetahuan yang luas terkaid dengan eksplore diri yang akan mereka dapatkan (Aberšek et al., 2015; Dani, 2009; Jgunkola \& Ogunkola, 2013; Liu, 2009; Yuenyong \& Narjaikaew, 2009). Secara kasat mata, siswa sekolah Adiwiyata tidak hanya dibekali pengetahuan konseptual, namun juga dibekali dengan pengetahuan faktual. Sehingga siswa terbiasa menggunakan pengalamannya untuk menyelesaikan permasalahan pada konteks-konteks yang baru.

Kemampuan siswa sekolah adiwiyata dalam mengidentifikasi konteks-konteks sains merupakan kegiatan situasi nyata yang tidak secara khusus diangkat dari materi, melainkan diangkar dari kehidupan sehari-hari. Sehingga aspek konteks yang saat ini telah dimiliki oleh siswa Sekolah Adiwiyata bukan hanya merujuk pada subjek materi yang diajarkan tetapi tindakan yang dilakukan dan diberikan sesuai dengan situasi nyata lingkungan siswa yang akan memberikan pengalaman menarik untuk menerapkan konsep-konsep sains dalam kehidupan (Holbrook \& Rannikmae, 2009; Jgunkola \& Ogunkola, 2013; Norris \& Phillips, 2003; Susilastri \& Rustaman, 2015). Berdasarkan hasil temuan peneliti dengan penelitian sebelumnya tampak jelas bahwa siswa dengan sekolah yang erat kaitannya dengan alam memungkinkan untuk memiliki kemampuan menggunakan pemahaman dan pengalaman menjadi salah satu keterampilan yang akan dipakai siswa untuk dapat menyelesaikan masalah dengan menggunakan konsep sains.

Aspek kedua hasil penelitian terkait kemampuan literasi sains siswa SD di Sekolah Adiwiyata pada aspek konten terlihat bahwa siswa Sekolah Adiwiyata terlihat memiliki keyakinan diri bahwa sains memiliki peran penting dalam kehidupan, sehingga keyakinan untuk melaksanakan segala sesuatu yang bersumber pada sains sangat tinggi. Hasil ini jelas bermakna bahwa siswa sekolah Adiwiyata tidak hanya menjadikan sains sebaga fakta dan konsep saja, namun merujuk pada tataran prinsip hidup siswa, sehingga prinsip hidup yang berasaskan sains menjadi salah satu pembeda bahwa sains merupakan keterampilan penalaran (Afni \& Rokhimawan, 2018; Susilastri \& Rustaman, 2015; Windyariani, 2018). Aspek konten yang sudah terinternaliasi secara terus menerus dalam pemikiran siswa di sekolah Adiwiyata hakikatnya juga mengarhkan peserta didik pada situasi nyata lingkungan dan kehidupan sehari-hari. Karena lingkungan di sekolah Adiwiyata menjadi sarana tempat bermai untuk mengikutsertakan berbagai kecerdasan yang dimiliki siswa, menstimulasi perkembangan kesehatan siswa, serta memperoleh output pem belajaran yang akan bertahan lama.

Hal tersebut sesuai dengan beberapa temuan hasil penelitian sebelumnya bahwa alam dan lingkungan disajikan sekolah bukan hanya penyediaan tumbuhan yang bervariasi melainkan tempat untuk mengenal situasi nyata, memelihara dan menyembuhkan, menciptakan banyak tempat praktik, hidup dengan suara, dan kompleksitas perolehan pengetahuan (Foster \& Shiel-Rolle, 2011; Gayford \& Saveland, 1978; Holbrook \& Rannikmae, 2009; Susilastri \& Rustaman, 2015). Ketersediaan lingkungan dan cara pandang sekolah Adiwiyata terhadap lingkungan sekitar diyakini sebagai salah satu hal yang menyebabkan aspek konten siswa sekolah Adiwiyata memiliki hasil yang lebih tinggi berdasarkan norma kategorisasi yang telah di bahas sebelumnya. Pemerolehan aspek konten yang merujuk pada keyakinan siswa dalam melaksanakan prinsip sains sebagai landasan berbuat merupakan salah satu hal yang sangat difasilitasi oleh sekolah Adiwiyata sebagai program dengan basis lingkungan. Hal lainnya juga tergambar bahwa dalam penguasaan konten, 
siswa SD di Sekolah Adiwiyata memiliki cara pandang yang luas dalam menyelesaikan masalah yang berkenaan dengan lingkungan dengan pola pikir sistematis sesuai dengan petunjuk kerja sains.

Aspek ketiga terkait dengan kemampuan literasi sains siswa sekolah dasar di sekolah Adiwiyata adalah sikap literasi sains. Hasil penelitian menunjukkan bahwa siswa sekolah Adiwiyata memiliki kecenderungan yang tinggi terkait minat terhadap sains, mempercayai bahwa sains merupakan rumpun ilmu yang berguna untuk mencapai cita-cita siswa, serta memiliki perhatian terhadap sains bahwa ilmu sains menjadikan pribasi yang menghargai alam, bahkan beberapa siswa menyatakan bahwa senantiasa melakukan pengamatan yang berulang untuk memastikan kebenaran data dan informasi yang diperoleh. Hasil ini jelas membuktikan bahwa pada aspek sikap, siswa adiwiyata memiliki kepekaan terhadap pentingnya sains sebagai salah satu rumpun ilmu yang memungkinkan mereka memilik keterampilan. Sekolah Adiwiyata dengan program unggulan lingkungan dan karakter peduli lingkungan menjadi daya tarik tersendri, sehingga perlakuan yang diberikan oleh sekolah Adiwiyata memberikan kontribusi yang baik terhadap peningkatan aspek keterampilan sikap literasi sains bagi siswa (Afni \& Rokhimawan, 2018; Pratiwi et al., 2019; Susilastri \& Rustaman, 2015; Yuliati, 2017). Temuan dan hasil penelitian yang relevan menginformasikan bahwa sikap literasi sains siswa di sekolah adiwiyata merupakan keunggulan yang dicapai karena adanya kontribusi yang diberikan oleh siswa berupa keterampilan sains yang sesuai dengan kebutuhan hidup siswa dan sering ditemui dalam kehidupannya, sehingga hal ini yang meyakinkan bahwa sains sebagai salah satu rumpun ilmu yang mengajarkan banyak hal dalam menumbuh kembangkan sikap yang peduli lingkungan.

Temuan-temuan kemampuan literasi sains siswa SD di sekolah Adiwiyata pada tiga aspek dapat disimpulkan bahwa ke-khas-an sekolah dengan berbagai slogan dan kegiatan yang berbasis peduli lingkungan menjadi alasan kuat pembentukan aspek konten, konteks, dan sikap literasi sains. Pembentukan kemampuan literasi sains yang ada di Sekolah Adiwiyata merupakan temuan baru yang sudah selayaknya menjadi keseriusan bagi seluruh elemen untuk menjadikan Adiwiyata sebagai sekolah rujukan sebagai pilot project atau basis sekolah dengan mengedepankan kepedulian lingkungan sebagai langkah awal menyiapkan kompetensi siswa sekolah dasar dalam memperoleh kompetensi abad 21 yaitu literasi sains. Kajian terkait dengan kemampuan literasi sains siswa SD di Sekolah Adiwiyata tentunya menjadi topik pembahasan yang sangat menarik. Oleh sebab itu, penelitian ini perlu dilanjutkan dengan melihat pengaruh dan kontribusi sekolah Adiwiyata dalam pembentukan perilaku literasi sains. Hal itu dilakukan agar hasil penelitian memiliki bukti empiric terkait dengan ada atau tidaknya pengaruh sekolah Adiwiyata dalam membentuk perilaku literasi sains siswa SD di sekolah. Saat ini, penelitian hanya di batasi pada studi deskripsi karena peneliti ingin mengungkap gambaran kemampuan literasi sains siswa saja. Sehingga kedepan hendaknya dapat dilakukan penelitian lanjutan sebagaimana rekomendasi yang telah peneliti sarankan.

\section{SIMPULAN}

Berdasarkan hasil penelitian dapat disimpulkan bahwa pada aspek konteks, siswa SD Adiwiyata cukup mampu dalam menjawab beberapa topik yang berkaitan dengan kehidupan sehari-sehari dengan mengidentifikasi aspek-aspek sains. Hal yang sama juga terlihat pada aspek konten, siswa SD Adiwiyata memiliki keyakinan bahwa sains bukan hanya berkaitan dengan fakta dan konsep saja, namun siswa SD Adiwiyata meyakini bahwa sains menjadi prinsip hidup yang berguna dalam pemecahan permasalahan yang erat kaitannya dengan kehidupan sehari-hari. Selanjutnya, aspek sikap literasi sains siswa sekolah Adiwiyata berdasarkan pembahasan yang telah dilakukan jelas bahwa siswa Adiwiyata memiliki kecenderungan yang tinggi terhadap sains, serta beberapa siswa senantiasa melakukan percobaan atau membuktikan segala sesuatu berdasarkan percobaan atau hasil Tanya jawab yang dilakukan secara berulang-ulang. Ketiga temuan terkait dengan kemampuan literasi sains siswa SD di sekolah Adiwiyata diyakini karena kontribusi lingkungan yang disajikan sekolah serta ke-khas-an yang dimiliki sekolah dalam menerapkan pola pembiasan dengan slogan peduli dan berbudaya lingkungan. 


\section{REFERENSI}

Aberšek, M. K., Dolenc, K., Flogie, A., \& Koritnik, A. (2015). New Natural Science Literacies Of Online Research And Comprehension: To teach or not to teach. Journal of Baltic Science Education, 14(4), 460-473.

Afni, N., \& Rokhimawan, M. A. (2018). Literasi Sains Peserta Didik Kelas V di MIN Tanuraksan Kebumen. Al-Bidayah: Jurnal Pendidikan Dasar Islam, 10(1), 47-68.

Azwar, S. (2017). Metode Penelitian Psikologi. Pustaka Belajar.

Bond, D. (1989). In pursuit of chemical literacy: A Place For Chemical Reactions. Journal of Chemical Education, 66(2), 157-160.

Dani, D. (2009). Scientific Literacy And Purposes For Teaching Science: A Case Study Of Lebanese Private School Teachers. International Journal of Environmental and Science Education, 4(3), 289-299.

DeBoer, G. E. (2000). Scientific literacy: Another look at its historical and contemporary meanings and its relationship to science education reform. Journal of Research in Science Teaching, 37(6), 582-601.

Eisenhart, M., Finkel, E., \& Marion, S. F. (1996). Creating the conditions for scientific literacy: A re-examination. American Educational Research Journal, 33(2), 261-295.

Foster, J., \& Shiel-Rolle, N. (2011). Building scientific literacy through summer science camps: a strategy for design, implementation and assessment. Science Education International, 22(2), 85-98.

Frydenberg, M., \& Andone, D. (2011). Learning for 21 st Century Skills. International Conference on Information Society, i-Society 2011, 314-318.

Gayford, C. G., \& Saveland, R. N. (1978). Handbook of Environmental Education. In British Journal of Educational Studies (Vol. 26, Nomor 1).

Holbrook, J., \& Rannikmae, M. (2009). The meaning of scientific literacy. International Journal of Environmental and Science Education, 4(3), 275-288.

Jgunkola, B. J., \& Ogunkola, B. J. (2013). Scientific Literacy: Conceptual Overview, Importance and Strategies for Improvement. Journal of Educationai and Sociai Research, 3(1), 265-274.

Liu, X. (2009). Beyond science literacy: Science and the public. International Journal of Environmental and Science Education, 4(3), 301-311.

Norris, S. P., \& Phillips, L. M. (2003). How Literacy in Its Fundamental Sense Is Central to Scientific Literacy. Science Education, 87(2), 224-240.

Pratiwi, S. N., Cari, C., \& Aminah, N. S. (2019). Pembelajaran IPA Abad 21 dengan Literasi Sains Siswa. Jurnal Materi dan Pembelajaran Fisika (JMPF), 9(1), 34-42.

Susilastri, S. D., \& Rustaman, N. Y. (2015). Students'environmental Literacy Profile in School-Based Nature and in School that Implement the Adiwiyata Program. 263-266.

Windyariani, S. (2018). Kemampuan Literasi Sains Siswa SD Pada Konteks Melestarikan Capung. Biosfer: Jurnal Pendidikan Biologi, 10(1), 17-21.

Yuenyong, C., \& Narjaikaew, P. (2009). Scientific literacy and thailand science education. International Journal of Environmental and Science Education, 4(3), 335-349.

Yuliati, Y. (2017). Literasi Sains Dalam Pembelajaran IPA. Jurnal Cakrawala Pendas, 3(2), 21-28. 